\title{
Effect of acute administration of cocaine on pituitary gonadotrophin secretion in female rats
}

\author{
T. S. King ${ }^{1,2}$, M. McNichol ${ }^{2}$, M. S. Canez ${ }^{2}$, M. A. Javors ${ }^{3}$ \\ and R. S. Schenken ${ }^{2}$ \\ Departments of ${ }^{1}$ Cellular and Structural Biology, ${ }^{2}$ Obstetrics and Gynecology and ${ }^{3}$ Psychiatry, \\ The University of Texas Health Science Center, San Antonio, TX 78229-3900, USA
}

\begin{abstract}
The aim of this study was to characterize the acute effects of cocaine administration on pituitary gonadotrophin secretion in adult female rats. Ovariectomized, oestradioltreated rats were infused i.v. with $0.1 \mathrm{ml}$ normal saline or $2 \mathrm{mg}$ cocaine hydrochloride $\mathrm{kg}^{-1}$. Blood samples were collected immediately before cocaine infusion and at 3 , 10, 30 and $60 \mathrm{~min}$ after cocaine infusion. Circulating $\mathrm{LH}$ concentrations were increased by $\mathbf{1 0}$ min after cocaine administration $(P<0.05$ versus saline-treated controls $)$ and decreased thereafter. Serum FSH concentrations were not significantly different from those of saline-infused controls at any time. In a second experiment, oestradioltreated, ovariectomized rats were infused i.v. with: saline only, $2 \mathrm{mg}$ cocaine hydrochloride $\mathrm{kg}^{-1}$ in saline, $200 \mathrm{ng}$ synthetic GnRH in $100 \mu$ I PBS or 200 ng synthetic GnRH plus $2 \mathrm{mg}$ cocaine hydrochloride $\mathrm{kg}^{-1}$ in PBS. Blood samples were collected immediately before drug infusions
\end{abstract}

and 20 min later. Cocaine had no effect on either GnRHstimulated LH or FSH secretion. In a third experiment, pituitary cells were obtained from oestradiol-treated, ovariectomized rats. The cell cultures were exposed to $25 \mathrm{ng}$ cocaine hydrochloride $\mathrm{ml}^{-1}, \mathbf{1 0}^{-10}-\mathbf{1 0}^{-7} \mathrm{~mol} \mathrm{GnRH}$ $\mathrm{l}^{-1}$ with and without $25 \mathrm{ng}$ cocaine hydrochloride $\mathrm{ml}^{-1}$, or vehicle only. Medium was collected before and after exposure to $\mathrm{GnRH}$ to determine concentrations of secreted LH and FSH. Similar to the results of the second study, cocaine had no effect on GnRH-stimulated LH or FSH secretion from pituitary cells in vitro. On the basis of these results it is suggested that acutely administered cocaine stimulates release of hypothalamic $\mathrm{GnRH}$, which, in turn, stimulates pituitary gonadotrophin secretion. Acute administration of cocaine does not appear to affect pituitary gonadotrophin secretion directly.

\section{Introduction}

Cocaine is the second most commonly used illicit drug (after marijuana) in the US and is the illicit drug mentioned most frequently by patients brought to emergency departments in most US cities (Drug Abuse Warning Network, 2000). In 1998, approximately 23 million Americans (11\% of the country's total population) aged 12 years or older reported using cocaine in their lifetimes, 4 million $(2 \%)$ reported cocaine use in the past year and 1.7 million $(0.8 \%)$ reported current cocaine use (National Household Survey on Drug Abuse, 2000). Among non-pregnant women of childbearing age, $>10 \%$ reported using illicit drugs including cocaine in the previous month. Clinical case studies indicate that cocaine alters normal reproductive function, including disruption of normal menstrual cyclicity and decreased libido in women who abuse this drug chronically (Siegel, 1982; Cocores et al., 1986; Teoh et al., 1994). Cocaine administration disrupts oestrous cyclicity and normal rates of ovulation in rats (King et al., 1990, 1993) and menstrual cyclicity and ovulation rates in monkeys (Potter et al., 1998, 1999). The effects of cocaine

Email: kingt@uthscsa.edu on cyclic reproductive function, including circulating $\mathrm{LH}$ concentrations, oestrous cyclicity and rates of ovulation in rats are dose-dependent and, at higher doses, may be irreversible (King et al., 1993). Despite the growing evidence that cocaine disrupts normal reproductive cyclicity, few studies have attempted to define the site of action of cocaine within the reproductive neuroendocrine axis.

Cocaine has no effect on GnRH-stimulated increases in serum $\mathrm{LH}$ and FSH concentrations in ovariectomized cynomolgus monkeys (Chen et al., 1998) and cocaine inhibits both noradrenaline- and phorbol ester-stimulated $\mathrm{GnRH}$ release from slices of rat hypothalamus in vitro (King et al., 1992, 1993). On the basis of the results of these studies, it was hypothesized that cocaine induces female reproductive dysfunction by disrupting release of $\mathrm{GnRH}$ from the hypothalamus, with resultant disturbances in cyclic reproductive function. In contrast, several studies have shown that serum gonadotrophin concentrations increase transiently within minutes of administration of cocaine to female rhesus monkeys (Mello et al., 1990a,b) and women (Mendelson et al., 2001). These investigators have suggested that acute exposure to cocaine stimulates a burst of hypothalamic GnRH release with a resultant 
transient increase in circulating $\mathrm{LH}$ concentrations (Mello and Mendelson, 1997). Similar studies to examine the acute effects of cocaine on pituitary gonadotrophin secretion in a rodent model have not been reported. Characterization of the acute effects of cocaine on pituitary gonadotrophin secretion could provide valuable information concerning both the site and mechanism of action to explain the effects of this drug on cyclic reproductive function in females.

The aim of the present study was to determine whether acute administration of cocaine directly affects pituitary gonadotrophin secretion in female rats by characterizing the acute effects of cocaine on: (i) LH and FSH concentrations in ovariectomized, oestrogen-replaced rats; (ii) GnRH-stimulated pituitary $\mathrm{LH}$ and $\mathrm{FSH}$ secretion in ovariectomized, oestrogen-replaced rats; and (iii) GnRHstimulated $\mathrm{LH}$ and FSH secretion from pituitary cells obtained from ovariectomized, oestrogen-treated rats.

\section{Materials and Methods}

\section{Animals}

All the rats used in these experiments were adult female Sprague-Dawley rats (125-135 g at delivery) (Charles River Laboratories Inc., Wilmington, MA). Rats were housed in groups of three per clear plastic cage and maintained in an automatically controlled cycle of $14 \mathrm{~h}$ light:10 h dark (lights on at 06:00 $\mathrm{h}$ daily). The rats were provided with food (Wayne Lab-Blox) and fresh tap water ad libitum. Oestrous cyclicity was monitored by daily (09:00-10:00 h) vaginal cytology through a minimum of two complete cycles for each rat. Rats with irregular oestrous cycles were excluded from the study. Each experimental protocol involving the use of animals was reviewed and approved by the Institutional Animal Care and Use Committee (IACUC), The University of Texas Health Science Center at San Antonio, San Antonio, Texas.

\section{Animal surgery}

Oestradiol benzoate-treated, ovariectomized rats were used to normalize ovarian steroid concentrations in these experiments. Rats in dioestrus were anaesthetized with Rompun cocktail (100 mg ketamine hydrochloride $\mathrm{ml}^{-1}$ : Ketaset, Aveco Company Inc., Fort Dodge, IA; 20 mg xylazine hydrochloride $\mathrm{ml}^{-1}$ : AnaSed, Lloyd Laboratories, Shenandoah, IA; 60:40, v/v) i.m. and ovariectomized bilaterally. On each of days 19-21 after ovariectomy, the rats were injected s.c. at 09:00 h with $50 \mu \mathrm{g}$ oestradiol benzoate in sesame oil $\mathrm{kg}^{-1}$ body weight (Sigma Chemical Co., St Louis, MO). On day 19 after ovariectomy, the rats were also anaesthetized i.m. with Rompun cocktail. The left jugular vein of each rat was cannulated with Silastic tubing that extended from the right atrium through the dorsum of the neck region. The rats were housed one per cage after this time. The tubing was later connected to additional tubing leading to the outside of the cage, allowing blood collection without the necessity of handling the rat. This tubing was weighted lightly and attached to a swivel above the cage. As the rat moved around its cage, slack in the cannula was taken up by this system, thus preventing the rat from accessing and damaging the cannula. Patency of the cannulae was maintained by regular flushing with heparinized saline.

\section{Gonadotrophin secretion in vivo}

At 10:00 $\mathrm{h}$ on the day of the third oestradiol benzoate injection, a single $0.5 \mathrm{ml}$ blood sample was collected over a period of 30-60 s from each rat via the indwelling venous cannula (time 0). The rats were divided into two experimental treatment groups: a group of eight rats infused via the indwelling jugular cannula with $0.2 \mathrm{ml}$ saline vehicle and a group of eight rats infused via the indwelling cannula with $2 \mathrm{mg}$ cocaine hydrochloride $\mathrm{kg}^{-1}$ (Sigma Chemical Co.). This dosage of cocaine was chosen to provide serum concentrations of the drug comparable with those in humans who reported "feeling high" within minutes of self-administering the drug (Jatlow, 1987; Canez et al., 1992). Blood samples $(0.5 \mathrm{ml})$ were collected at 3,10 , 30 and $60 \mathrm{~min}$ after saline or cocaine infusion. Blood samples were centrifuged at $2300 \mathrm{~g}$ for $5 \mathrm{~min}$ as collected; the serum was removed and stored at $-20^{\circ} \mathrm{C}$ until assayed for $\mathrm{LH}$ and $\mathrm{FSH}$ by radioimmunoassay.

In the second half of this experiment, oestradiol benzoate-treated, ovariectomized rats were infused at 10:00 $\mathrm{h}$ via the indwelling venous cannula with $100 \mu \mathrm{l}$ PBS only ( $n=9$ rats) or $2 \mathrm{mg}$ cocaine hydrochloride in $\mathrm{PBS} \mathrm{kg}^{-1}$ ( $n=8$ rats) ('no-GnRH' groups). After $20 \mathrm{~min}$, a single $0.5 \mathrm{ml}$ blood sample was collected within a 30-60 s time interval. Two additional groups of rats were infused via the indwelling cannula with 200 ng synthetic GnRH in $100 \mu \mathrm{l}$ PBS vehicle ( $\mathrm{pH} 7.0$; 'GnRH' groups), followed immediately by $100 \mu \mathrm{l}$ PBS or $2 \mathrm{mg}$ cocaine hydrochloride $\mathrm{kg}^{-1}$. An additional $0.5 \mathrm{ml}$ blood sample was collected $20 \mathrm{~min}$ after $\mathrm{GnRH}$ infusion. The $20 \mathrm{~min}$ post-GnRH infusion interval was chosen to measure the maximum increase in $\mathrm{GnRH}$ stimulated $\mathrm{LH}$ secretion and the stimulating effect of cocaine is still present (see Fig. 1) (Aiyer et al., 1974; Libertun et al., 1974). Blood samples were centrifuged at $2300 \mathrm{~g}$ for $5 \mathrm{~min}$ as collected; the serum was removed and stored at $-20^{\circ} \mathrm{C}$ until assayed for $\mathrm{LH}$ and $\mathrm{FSH}$ by radioimmunoassay.

\section{Gonadotrophin secretion in vitro}

Oestradiol benzoate-treated, ovariectomized rats $(n=26)$ were killed by decapitation. The anterior pituitary glands were removed rapidly and pooled together in cold Hepes buffer solution ( $\mathrm{pH}$ 7.2). The glands were minced finely with a sterile scalpel and scissors. The tissue was incubated with continuous stirring in a mixture of $0.1 \%(\mathrm{w} / \mathrm{v})$ hyaluronidase (Gibco, Santa Clara, CA), 0.35\% (w/v) collagenase (Gibco) and 3\% (w/v) bovine serum albumin (fraction V; Sigma Chemical Co.) at $37^{\circ} \mathrm{C}$ for $45 \mathrm{~min}$. After initial enzymatic cell dispersal, the mixture was centrifuged 
at $500 \mathrm{~g}$ for $2 \mathrm{~min}$. The resulting pellet was resuspended in Hepes buffer solution containing $0.25 \%(\mathrm{w} / \mathrm{v})$ viocase (Sigma Chemical Co.) and stirred for $15-30 \mathrm{~min}$ at $37^{\circ} \mathrm{C}$. The dispersed cells were counted using a haemocytometer and $>80 \%$ of the cells were diluted to a concentration of $2.5 \times 10^{5}$ viable cells $\mathrm{ml}^{-1}$ growth medium. Growth medium consisted of Dulbecco's modified Eagle's medium (DMEM) with the following substances: $10 \%$ horse serum, $2.5 \%$ fetal calf serum, $0.1 \mathrm{mmol}$ glutamine $\mathrm{l}^{-1}, 1 \%(\mathrm{w} / \mathrm{v})$ nonessential amino acids and penicillin-streptomycin (100 iu ml-1 and $100 \mu \mathrm{g} \mathrm{ml}^{-1}$, respectively). The cells were added to Falcon multi-well dishes (Falcon Plastics, Los Angeles, CA) in a volume of $0.5 \mathrm{ml}$ growth medium per well and incubated at $37^{\circ} \mathrm{C}$ in a water-saturated atmosphere of $5 \% \mathrm{CO}_{2}$ and $95 \%$ air. After 3 days to allow cell attachment, the original growth medium was discarded and the cells were washed three times with $500 \mu \mathrm{l}$ DMEM.

DMEM $(400 \mu \mathrm{l})$ containing final concentrations of $10^{-10}$, $10^{-9}$ or $10^{-7}$ mol synthetic GnRH I-1, or DMEM without $\mathrm{GnRH}$, was added to the wells. This range of $\mathrm{GnRH}$ concentrations was chosen on the basis of published reports using synthetic $\mathrm{GnRH}$ to stimulate $\mathrm{LH}$ and FSH release from dispersed rat pituitary cells in vitro (Drouin et al., 1976; Tang, 1980). DMEM (100 $\mu \mathrm{l})$ containing cocaine hydrochloride at a final concentration of $25 \mathrm{ng} \mathrm{ml}^{-1}$ was added at this time to half of the wells. An equal volume of DMEM without cocaine hydrochloride was added to the other wells. After $30 \mathrm{~min}$, the medium was removed from each well and stored at $-20^{\circ} \mathrm{C}$ for subsequent measurements of $\mathrm{LH}$ and $\mathrm{FSH}$ by radioimmunoassay.

\section{Gonadotrophin assays}

Serum LH concentrations were measured in duplicate using a rabbit anti-ovine LH antibody (No. 15; G. Niswender, Colorado State University, Fort Collins, CO) at a final dilution of 1:120 000. Purified ovine LH was iodinated with ${ }^{125}$ I to a specific activity of $304 \mu \mathrm{Ci} \mathrm{mg}{ }^{-1}$ according to the method of Hunter and Greenwood (1962). The standard was rat LH (NIDDK-LH-RP1) provided by A. Parlow (NIDDK, Bethesda, MD). Serum samples were diluted to a volume of $300 \mu \mathrm{l}$ with $0.5 \%(\mathrm{w} / \mathrm{v}) \mathrm{BSA}$ in $0.05 \mathrm{~mol}$ phosphate buffer $\mathrm{I}^{-1}$. Primary antibody $(100 \mu \mathrm{l})$ was added and the samples were incubated overnight at $4^{\circ} \mathrm{C}$. Labelled $\mathrm{LH}(100 \mu \mathrm{l})$ was then added to each sample. A suspension $(500 \mu \mathrm{l})$ of iron-containing polymer beads coated with donkey anti-rabbit gamma-globulin (1:3 dilution) was added to each sample and vortexed for $5 \mathrm{~min}$. The incubation was continued for another hour at room temperature. The samples were placed on a magnetic base for $15 \mathrm{~min}$ to separate bound from free hormone (AmerlexM Magnetic Particle Separations System; Amersham Corporation, Arlington Heights, IL). Supernatants were discarded and the radioactivity in the magnetically retrieved pellet was measured in a gamma counter. Maximum binding and non-specific binding were 25 and 1.9\%, respectively. Assay sensitivity was $0.88 \mathrm{ng}$ per tube. Intra-

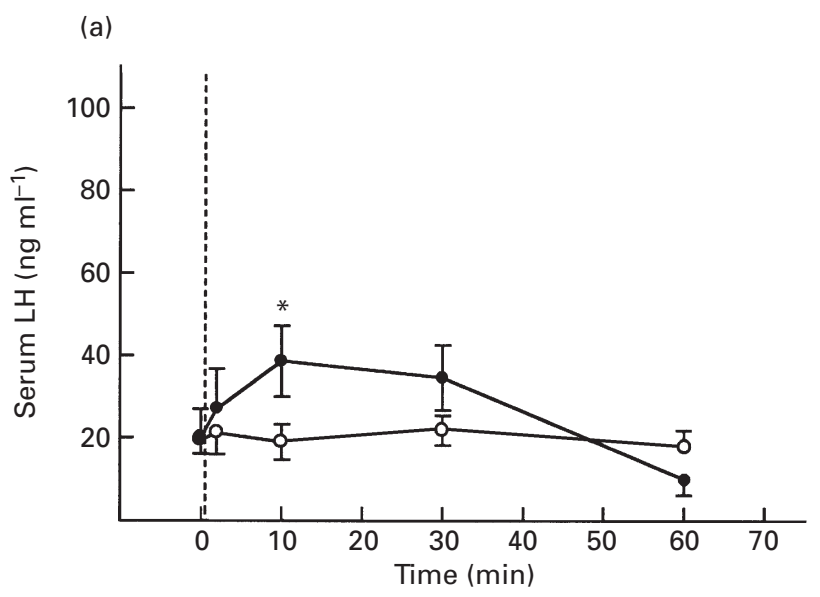

(b)

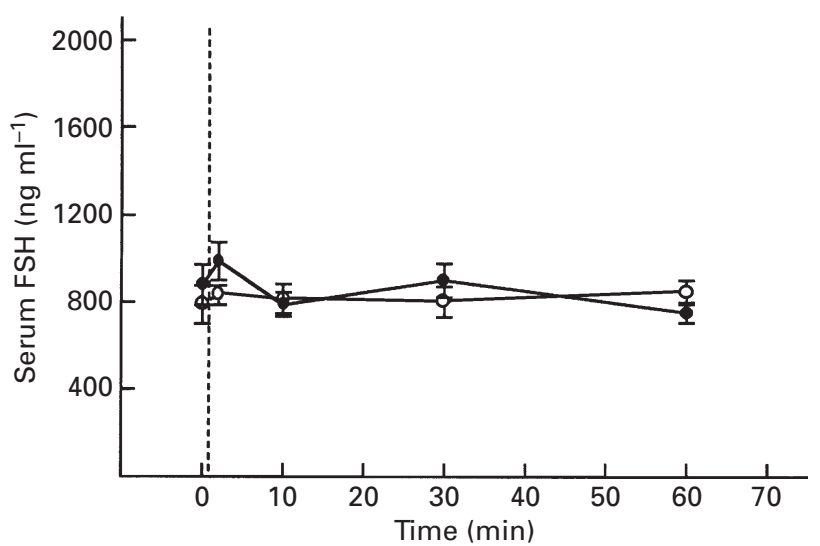

Fig. 1. Effects of acute administration of cocaine on pituitary (a) LH and (b) FSH secretion in ovariectomized, oestrogen-replaced rats. Rats were ovariectomized 3 weeks earlier and treated with oestrogen for the final 3 days of the experiment. Rats were divided into two treatment groups: i.v. saline administration $(\mathbf{O} ; n=8$ rats $)$ or i.v. administration of $2 \mathrm{mg}$ cocaine hydrochloride $\mathrm{kg}^{-1}(\bigcirc ; n=8$ rats). Dashed line indicates time of administration. On the final day, an initial blood sample was collected via a jugular vein cannula. Serum LH concentrations increased in response to the acute administration of cocaine infusion in ovariectomized, oestrogen-replaced rats. Serum LH concentrations subsequently decreased over the next $60 \mathrm{~min}$ to pre-cocaine infusion concentrations. Acute exposure to cocaine had no significant effect on serum FSH concentrations in ovariectomized, oestrogen-replaced rats. Data are expressed as mean \pm SEM. *Significantly different from saline-treated rats at this time $(P<0.05)$.

and interassay coefficients of variation were 5.5 and $6.7 \%$, respectively.

Serum FSH concentrations were measured using a specific hFSH antiserum (A. Parlow, NIDDK) at a final dilution of 1:125 000. Purified rat FSH was iodinated with 125 I to a specific activity of $365 \mu \mathrm{Ci} \mathrm{mg}{ }^{-1}$, according to the method of Hunter and Greenwood (1962). The standard was rat FSH (NIDDK-FSH-RP1; A. Parlow, NIDDK). Serum samples with diluent added to a total volume of $300 \mu \mathrm{l}$ were 

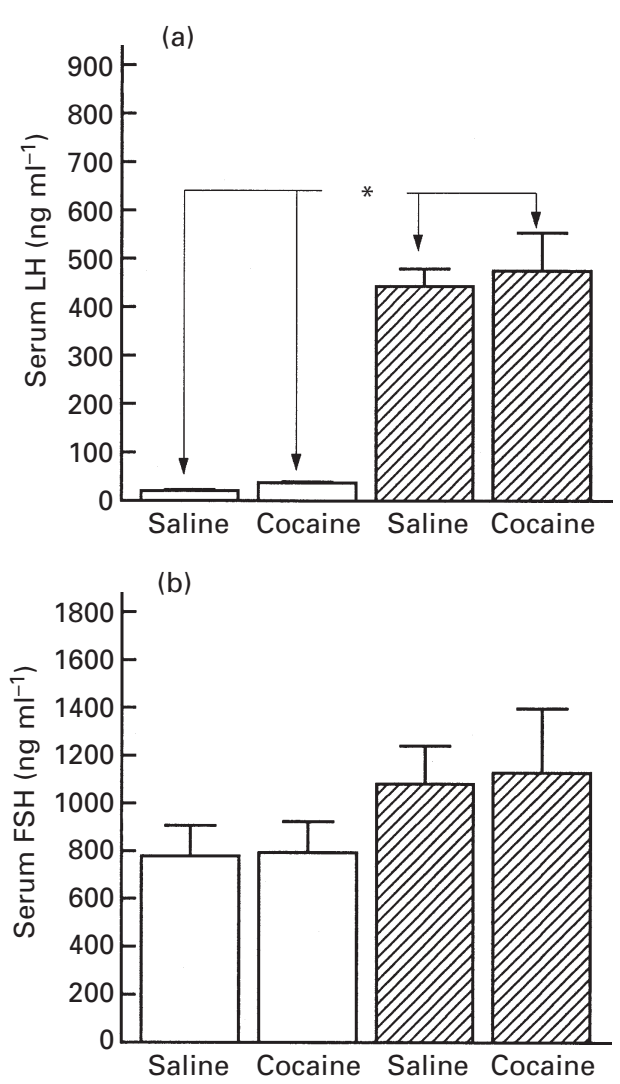

Fig. 2. Effect of acute administration of cocaine on GnRHstimulated (a) LH and (b) FSH secretion in ovariectomized, oestrogen-replaced rats. Rats were ovariectomized 3 weeks earlier and treated with oestrogen for the final 3 days of the study. On day 3 , two sets of rats were infused at 10:00 h via an indwelling venous cannula with $100 \mu \mathrm{l}$ PBS only $(n=9$ rats) or $2 \mathrm{mg}$ cocaine hydrochloride in PBS kg-1 ( $n=8$ rats) ('no-GnRH' groups; $\square$ ). These rats were not infused with GnRH. After $20 \mathrm{~min}$, a single $0.5 \mathrm{ml}$ blood sample was collected within a 30-60 s time interval. Two additional groups of rats were infused via the indwelling cannula with $200 \mathrm{ng}$ synthetic GnRH in $100 \mu \mathrm{l}$ PBS vehicle $(\mathrm{pH}$ 7.0; 'with $\left.\mathrm{GnRH}^{\prime} ; \mathbb{Z}\right)$, followed immediately by $100 \mu \mathrm{l}$ PBS $(n=8$ rats) or $2 \mathrm{mg}$ cocaine hydrochloride $\mathrm{kg}^{-1}$ ( $n=8$ rats). A $0.5 \mathrm{ml}$ blood sample was collected 20 min after the infusion of $\mathrm{GnRH}$ for determination of serum LH and FSH concentrations. Serum LH (but not FSH) concentrations increased minimally in response to cocaine in rats that had not been infused with GnRH. GnRH infusion resulted in a significant increase in serum $\mathrm{LH}$ concentrations $\left({ }^{*} P<0.001\right.$ versus the 'no $\mathrm{GnRH}^{\prime}$ saline-infused group). However, no significant differences between saline-infused controls and cocaine-treated animals were observed for GnRHstimulated LH or FSH release. Data are mean \pm SEM.

preincubated for $48 \mathrm{~h}$ at $4^{\circ} \mathrm{C}$. lodinated FSH $(100 \mu \mathrm{l})$ was added and the incubation was continued for an additional $72 \mathrm{~h}$ at $4^{\circ} \mathrm{C}$. At that time, $500 \mathrm{ml}$ of a suspension of ironcontaining polymer beads coated with donkey anti-rabbit gamma-globulin (1:2 dilution) was added to each sample. Bound and free hormone were separated (Amerlex-M Magnetic Separations System). After discarding the supernatant, radioactivity was measured in a gamma counter. Maximum binding and non-specific binding were 30 and $1.5 \%$, respectively. Assay sensitivity was 32 ng per tube. Intra- and interassay coefficients of variation were 5.2 and $5.9 \%$, respectively.

\section{Statistical analysis}

Data are expressed as mean \pm SEM. Differences within and among treatment groups were analysed initially by twoway ANOVA for repeated measures. Specific mean differences were evaluated further using a post-test for linear trends (Fig. 1; GraphPad: Prism, Version 2.0, San Diego, CA). Specific differences between controls and cocaine-treated groups were analysed further using the Bonferroni test (Figs 2 and 3; GraphPad: Prism, Version 2.0). The level of significance was $P \leqslant 0.05$.

\section{Results}

The acute effects of cocaine on serum concentrations of $\mathrm{LH}$ and FSH in ovariectomized, oestrogen-replaced rats are shown (Fig. 1). Mean serum $\mathrm{LH}$ and FSH concentrations were $20.5 \pm 4.5$ and $815 \pm 82 \mathrm{ng} \mathrm{ml}^{-1}$, respectively, in ovariectomized, oestrogen-treated rats. Within 10 min after i.v. administration of $2 \mathrm{mg}$ cocaine hydrochloride $\mathrm{kg}^{-1}$, circulating LH (Fig. 1a) and FSH (Fig. 1b) concentrations increased approximately $119 \%(P<0.05)$ and $13 \%$ (not significant), respectively, versus saline-infused controls. Serum LH concentrations decreased during the next $60 \mathrm{~min}$ to concentrations similar to those observed before administration of cocaine.

The acute effects of cocaine on GnRH-stimulated increases in serum $\mathrm{LH}$ and $\mathrm{FSH}$ concentrations in ovariectomized, oestrogen-replaced rats are shown (Fig. 2). Basal concentrations of serum $\mathrm{LH}$ and FSH were $21.4 \pm 2.3$ and $780.2 \pm 127.4 \mathrm{ng} \mathrm{ml}^{-1}$, respectively, in ovariectomized, oestrogen-treated rats. Intravenous infusion of $100 \mathrm{ng}$ synthetic $\mathrm{GnRH} \mathrm{ml}^{-1}$ resulted in significant increases in both $\mathrm{LH}$ and $\mathrm{FSH}$ concentrations compared with basal concentrations. Administration of cocaine had no significant effect on $\mathrm{GnRH}$-induced increases in either $\mathrm{LH}$ or $\mathrm{FSH}$ responses to GnRH infusion.

The acute effects of cocaine on GnRH-stimulated LH and FSH secretion from pituitary cells in culture are shown (Fig. 3). Basal concentrations of $\mathrm{LH}$ and FSH were $72 \pm 12$ and $89 \pm 18 \mathrm{ng}$ per $5 \times 10^{5}$ cells, respectively, in cultures of rat pituitary cells obtained from ovariectomized, oestrogentreated rats. Addition of $25 \mathrm{ng}$ cocaine hydrochloride $\mathrm{ml}^{-1}$ to the cell cultures had no effect on either $\mathrm{LH}$ or FSH release. With addition of synthetic $\mathrm{GnRH}$ at concentrations ranging from $10^{-10}$ to $10^{-7} \mathrm{~mol} \mathrm{I}^{-1}, \mathrm{LH}$ and $\mathrm{FSH}$ release increased in a dose-dependent fashion. Addition of $10^{-7}$ mol $\mathrm{GnRH}{ }^{-1}$ resulted in a $676-743 \%$ increase relative to basal $\mathrm{LH}$ release and $228-245 \%$ increase relative to basal FSH release. The addition of 25 ng cocaine hydrochloride $\mathrm{ml}^{-1}$ had no effect on the GnRH-stimulated, dose- 
(a)

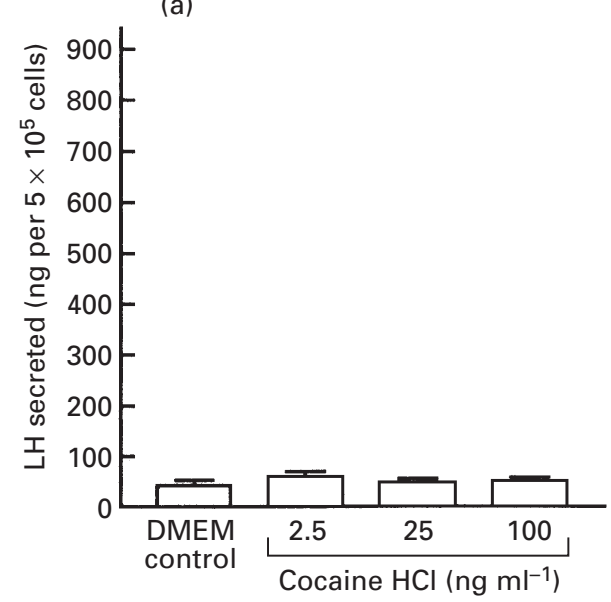

(c)

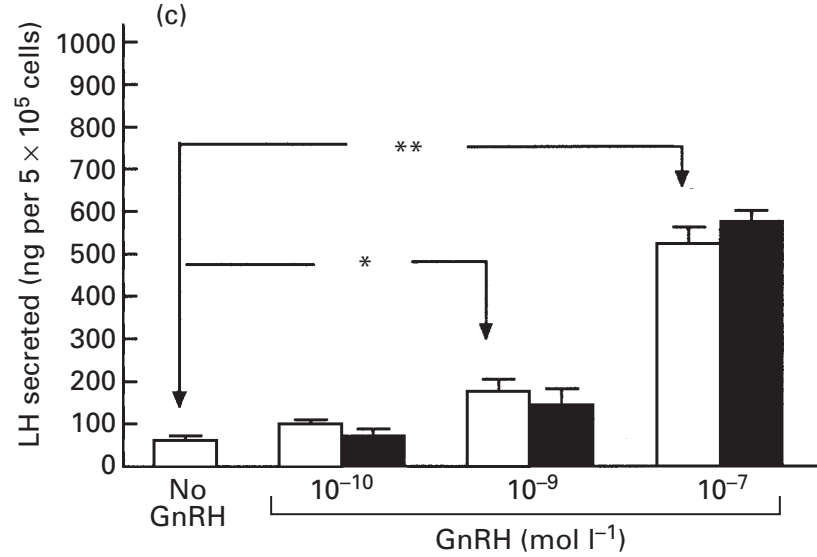

(b)

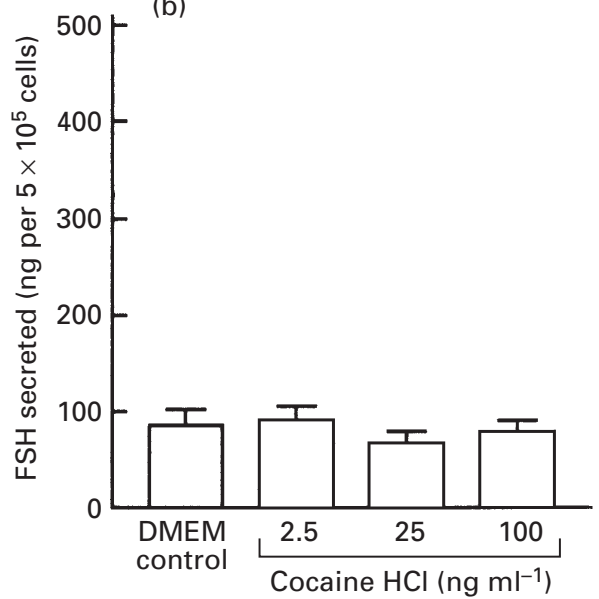

(d)

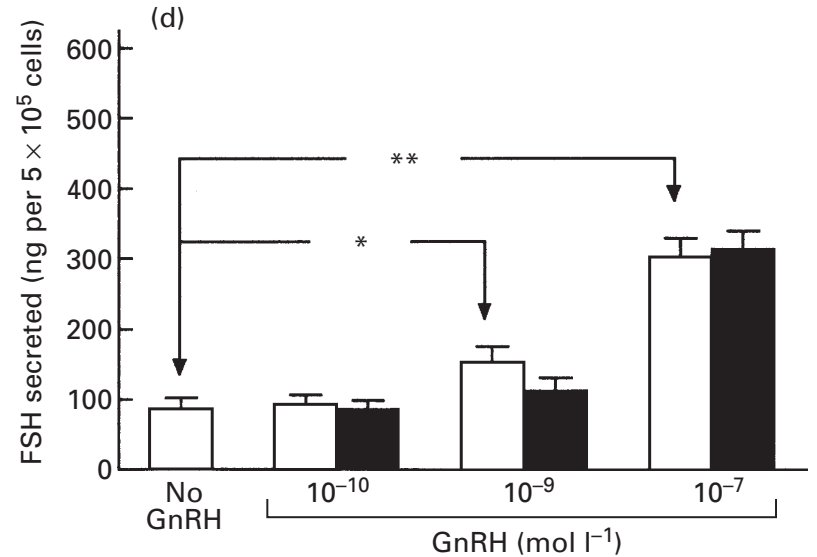

Fig. 3. Effect of cocaine on GnRH-stimulated LH and FSH secretion from cultured rat pituitary cells. Anterior pituitary glands were collected from oestradiol benzoate-treated, ovariectomized rats. Dispersed pituitary cells were maintained in culture at a concentration of $2.5 \times 10^{5}$ viable cells per $\mathrm{ml}$ growth medium. LH and FSH were measured in aliquots of medium collected 30 min after exposure of the cells to GnRH or cocaine or both. $(a, b)$ Exposure of the cells to 2.5-100.0 ng cocaine hydrochloride (cocaine $\mathrm{HCl}) \mathrm{ml}^{-1}$ had no effect on LH or FSH release. (c,d) Exposure of the cells to $10^{-10}-10^{-7} \mathrm{~mol} \mathrm{GnRH} \mathrm{^{-1 }}$ stimulated LH and FSH release $(\square)$. Concurrent exposure of the cells to $25 \mathrm{ng}$ cocaine hydrochloride $\mathrm{ml}^{-1}$ had no effect on $\mathrm{GnRH}$-stimulated $\mathrm{LH}$ or FSH release ( $\square$ ). Data are expressed as mean \pm SEM. $* P<0.01$ and $* * P<0.001$.

dependent release of LH and FSH from cultured pituitary cells.

\section{Discussion}

The results of the present study demonstrate that acute administration of cocaine stimulates pituitary gonadotrophin secretion in ovariectomized rats transiently but has no effect on $\mathrm{GnRH}$-stimulated pituitary gonadotrophin secretion in ovariectomized rats. Furthermore, cocaine has no apparent effect on $\mathrm{GnRH}$-stimulated gonadotrophin secretion from pituitary cells in culture. On the basis of these results it is suggested that acutely administered cocaine stimulates the release of hypothalamic $\mathrm{GnRH}$, which, in turn, stimulates pituitary gonadotrophin secretion. Acute administration of cocaine does not appear to affect pituitary gonadotrophin secretion directly.
Cocaine abuse is often associated with reproductive dysfunction in women (Siegel, 1982; Cocores et al., 1986; Teoh et al., 1994). Cocaine abuse has also been associated with altered pituitary volume (Teoh et al., 1993) and secretion of pituitary hormones, including gonadotrophins, in humans (Mendelson et al., 1989). However, potential sites of action and the mechanism of action for cocaineinduced reproductive dysfunction have not been defined precisely. Over the past two decades several research groups have attempted to define the effects of cocaine on pituitary function using animal models. Steger et al. (1981) reported that acute i.p. administration of 10 or $20 \mathrm{mg}$ cocaine hydrochloride $\mathrm{kg}^{-1}$ increased, whereas acute i.p. administration of $40 \mathrm{mg}$ cocaine hydrochloride $\mathrm{kg}^{-1}$ decreased, serum LH concentrations in ovariectomized rats. Dada and Horacek (1991) showed that i.v. injection of cocaine hydrochloride at concentrations of $1-3 \mathrm{mg} \mathrm{kg}^{-1}$ 
decreased circulating $\mathrm{LH}$ concentrations but had no apparent effect on circulating FSH concentrations in orchidectomized rats. King et al. (1993) reported that daily s.c. administration of $10 \mathrm{mg}$ cocaine hydrochloride $\mathrm{kg}^{-1}$ to rats undergoing regular oestrous cycles resulted in marked disruption of oestrous cyclicity and decreased ovulation rates. Likewise, Potter et al. (1999) demonstrated that daily i.v. administration of 1 or $2 \mathrm{mg}$ cocaine hydrochloride $\mathrm{kg}^{-1}$ throughout the follicular phase (days 2-14 of the oestrous cycle) leads to disruption of menstrual cyclicity and ovulation rates in rhesus monkeys.

Mello et al. (1990a,b) demonstrated that acute i.v. administration of 0.4 and $0.8 \mathrm{mg}$ cocaine hydrochloride $\mathrm{kg}^{-1}$ results in increased concentrations of circulating $\mathrm{LH}$ in female rhesus monkeys during the early follicular phase. In mid-luteal phase rhesus monkeys, administration of $0.4 \mathrm{mg}$ cocaine $\mathrm{kg}^{-1}$ had no effect on serum $\mathrm{LH}$ or $\mathrm{FSH}$ concentrations, whereas administration of $0.8 \mathrm{mg}$ cocaine $\mathrm{kg}^{-1}$ stimulated an increase in serum $\mathrm{LH}$ (but not $\mathrm{FSH}$ ) concentrations (Mello et al., 1993). Similarly, Mendelson et al. (2001) have shown that administration of $0.2 \mathrm{mg}$ cocaine $\mathrm{kg}^{-1}$ to women did not affect pituitary LH secretion but that administration of $0.4 \mathrm{mg}$ cocaine $\mathrm{kg}^{-1}$ stimulated significant increases in $\mathrm{LH}$ during both the follicular and luteal phases of their cycles. These studies indicate that the acute effects of cocaine on stimulation of pituitary gonadotrophin secretion are dependent on both dosage and cycle phase. Furthermore, Mello et al. (1990b, 1995) reported that i.v. administration of $0.4 \mathrm{mg}$ cocaine $\mathrm{kg}^{-1}$ significantly enhanced GnRH stimulation of $\mathrm{LH}$ and FSH in rhesus monkeys during the early follicular phase, an effect that may have occurred either at the pituitary gonadotroph or the hypothalamic $\mathrm{GnRH}$ neurones. The apparent differences between our studies using rats and monkeys and those of Mello et al. (1990a,b, 1993) using monkeys may be a function of differences in drug concentrations or other experimental parameters. Apart from such methodological differences, cocaine clearly has significant effects on the hypothalamic GnRH-pituitary gonadotrophin axis and, thus, on cyclic reproductive function. What is not as obvious is whether cocaine exerts these effects on hypothalamic $\mathrm{GnRH}$ release or pituitary gonadotrophin secretion.

Mello et al. (1990b) have shown that cocaine enhances GnRH-stimulated LH secretion in female rhesus monkeys. Using deconvolutional pulse analysis, these workers noted that cocaine does not affect the elimination half-life of $\mathrm{LH}$ and suggested that cocaine may stimulate a burst of hypothalamic $\mathrm{GnRH}$ release with a resultant transient increase in pituitary $\mathrm{LH}$ release. The results of the present study using ovariectomized, oestrogen-replaced rats, in which cocaine treatment caused a transient increase in circulating LH (but not FSH) concentrations, support their conclusion. However, acute i.v. administration of 2 or $4 \mathrm{mg}$ cocaine hydrochloride $\mathrm{kg}^{-1}$ decreased circulating concentrations of LH in ovariectomized rhesus monkeys but had no effect on GnRH-stimulated gonadotrophin secretion in ovariectomized rhesus monkeys (Chen et al., 1998). The results of Chen et al. (1998) compare favourably with the results of the present study in which cocaine had no effect on $\mathrm{GnRH}$-stimulated $\mathrm{LH}$ or $\mathrm{FSH}$ release either in vivo or in vitro. Thus, the acute administration of cocaine does not affect pituitary gonadotrophs directly but instead stimulates a short-lived burst of hypothalamic GnRH release.

Cocaine could interfere with the normal secretion of hypothalamic GnRH via multiple mechanisms. Hypothalamic $\mathrm{GnRH}$ release is modulated by noradrenergic, dopaminergic and serotoninergic systems (Kordon and Glowinski, 1972; Kalra and Kalra, 1983; Kalra, 1985). Changes in the patterns of aminergic activity regulating $\mathrm{GnRH}$ release could be expected to disrupt oestrous cyclicity in rats and menstrual cyclicity in primates. The effects of cocaine to alter aminergic neurotransmitter activity are well documented (for a review see Jatlow, 1987). Thus, it is not surprising that acute administration of cocaine, as shown in the present study, results in transient release of hypothalamic $\mathrm{GnRH}$. In contrast, chronic cocaine administration could downregulate the aminergic regulation of hypothalamic GnRH neurones and, thus, disrupt normal pulsatile GnRH secretion. In vitro, noradrenalinestimulated (King et al., 1990) and phorbol ester-stimulated (King et al., 1992) GnRH release is inhibited in slices of hypothalamic tissue obtained from rats injected s.c. with $10 \mathrm{mg}$ cocaine $\mathrm{kg}^{-1}$ for 2 weeks. Thus, it is reasonable to postulate a hypothalamic site of action for both the acute and chronic effects of cocaine on the reproductive neuroendocrine axis.

In conclusion, serum LH concentrations increase within 10 min of i.v. administration of cocaine to ovariectomized, oestrogen-replaced rats, an effect that could be attributed to an effect of the drug on either hypothalamic GnRH neurones or pituitary gonadotrophs. However, acute administration of cocaine had no effect on GnRH-stimulated increases in either serum $\mathrm{LH}$ or FSH in ovariectomized, oestrogenreplaced rats. Furthermore, $\mathrm{GnRH}$-stimulated $\mathrm{LH}$ and $\mathrm{FSH}$ secretion from pituitary cells in culture was unaffected by the addition of cocaine. These results indicate that acute exposure to cocaine does not have a direct effect on pituitary gonadotrophs in female rats. Without excluding possible direct effects of cocaine on ovarian function, it is suggested that an effect of this drug on hypothalamic $\mathrm{GnRH}$ neurones or the neurotransmitter systems regulating the hypothalamic GnRH neurones probably accounts for cocaine-induced cyclic reproductive dysfunction.

This work was supported by the National Institute on Drug Abuse grant DA-06039 and the National Institute of Health grant HD-10202 (Neuroendocrine Core). The authors would like to thank T-T. Gu, D. Frasier and I. Montoya for their technical assistance in these studies.

\section{References}

Aiyer MS, Chiappa SA and Fink G (1974) A priming effect of luteinizing hormone releasing factor on the anterior pituitary gland in the female rat Journal of Endocrinology 62 573-579 
Canez MS, Samuels MH, Luther MF, King TS and Schenken RS (1992) Cocaine impairs gonadotropin secretion in oophorectomized monkeys American Journal of Obstetrics and Gynecology 167 1785-1793

Chen EC, Samuels MH, Luther MF, King TS, Eddy CA, Siler-Khodr TM and Schenken RS (1998) Cocaine impairs follicular phase pulsatile gonadotropin secretion in rhesus monkeys Journal of the Society for Gynecologic Investigation 5 311-316

Cocores JA, Dackis CA and Gold MS (1986) Sexual dysfunction secondary to cocaine abuse in two patients Journal of Clinical Psychiatry 47 384-385

Dada MO and Horacek MJ (1991) Acute effects of intravenous administration of cocaine on circulating luteinizing hormone, folliclestimulating hormone and prolactin concentrations in rats Research Communications on Substance Abuse 12 197-208

Drouin J, Lagace L and Labrie F (1976) Estradiol-induced increase of the LH responsiveness to $\mathrm{LH}$ releasing hormone $(\mathrm{LHRH})$ in rat anterior pituitary cells in culture Endocrinology 99 1477-1481

Drug Abuse Warning Network Annual Medical Examiners Data 1998 (2000) Substance Abuse and Mental Health Services Administration, Office of Applied Studies Washington, DC: United States Department of Health and Human Services (DHHS Publication No. (SMA) 00-3408)

Hunter W and Greenwood FS (1962) Preparation of iodine-131 labelled human growth hormone of high specificity Nature 194 495-506

Jatlow PI (1987) Drugs of abuse profile: cocaine Clinical Chemistry 33 66B-71B

Kalra SP (1985) Neural circuits involved in the control of LHRH secretion: a model for estrous cycle regulation Journal of Steroid Biochemistry $\mathbf{2 3}$ 733-742

Kalra SP and Kalra PS (1983) Neural regulation of luteinizing hormone in the rat Endocrine Reviews 4 311-351

King TS, Schenken RS, Kang IS, Javors MA and Riehl RM (1990) Cocaine disrupts estrous cyclicity and alters the reproductive neuroendocrine axis in the rat Neuroendocrinology 51 15-22

King TS, Kang IS, Javors MA and Schenken RS (1992) Phorbol esters stimulate in vitro $\mathrm{GnRH}$ release from the hypothalamus of the estrogenprimed, ovariectomized rat: inhibitory effects of cocaine Neuroendocrinology 56 526-532

King TS, Canez MS, Gaskill S, Javors MA and Schenken RS (1993) Chronic cocaine disruption of estrous cyclicity in the rat: dose-dependent effects Journal of Pharmacology and Experimental Therapeutics 264 29-34

Kordon C and Glowinski J (1972) Role of hypothalamic monoaminergic neurons in the gonadotropin release-regulating mechanism Neuropharmacology 11 153-161

Libertun C, Cooper KJ, Fawcett CP and McCann SM (1974) Effects of ovariectomy and steroid treatment on hypophysial sensitivity to purified LH-releasing factor (LRF) Endocrinology 94 518-525

Mello NK and Mendelson JH (1997) Cocaine's effects on neuroendocrine systems: clinical and preclinical studies Pharmacology, Biochemistry and Behavior 57 571-599

Mello NK, Mendelson JH, Drieze JM and Kelly M (1990a) Acute effects of cocaine on prolactin and gonadotropins in female rhesus monkey during the follicular phase of the menstrual cycle Journal of Pharmacology and Experimental Therapeutics 254 815-823
Mello NK, Mendelson JH, Drieze JM and Kelly M (1990b) Cocaine effects on luteinizing hormone-releasing hormone-stimulated anterior pituitary hormones in female rhesus monkey Journal of Clinical Endocrinology and Metabolism 71 1434-1441

Mello NK, Sarnyai Z, Mendelson JH, Drieze JM and Kelly M (1993) Acute effects of cocaine on anterior pituitary hormones in male and female rhesus monkeys Journal of Pharmacology and Experimental Therapeutics 266 904-811

Mello NK, Sarnyai Z, Mendelson JH, Drieze JM and Kelly M (1995) The acute effects of cocaine on anterior pituitary hormones in ovariectomized rhesus monkeys Journal of Pharmacology and Experimental Therapeutics 272 1059-1066

Mendelson JH, Mello NK, Teoh SK, Ellingboe J and Cochin J (1989) Cocaine effects on pulsatile secretion of anterior pituitary, gonadal, and adrenal hormones Journal of Clinical Endocrinology and Metabolism 69 1256-1260

Mendelson JH, Sholar JW, Seigel AJ and Mello NK (2001) Effect of cocaine on luteinizing hormone in women during the follicular and luteal phases of the menstrual cycle and in men Journal of Pharmacology and Experimental Therapeutics 296 972-979

National Household Survey on Drug Abuse: Main Findings (2000) Substance Abuse and Mental Health Services Administration, Office of Applied Studies Washington, DC: United States Department of Health and Human Services (DHHS Publication No. (SMA) 00-3381)

Potter DA, Luther MF, Eddy CA, Siler-Khodr TM, King TS and Schenken RS (1998) Effects of follicular phase cocaine administration on menstrual and ovarian cyclicity in rhesus monkeys American Journal of Obstetrics and Gynecology 178 118-125

Potter DA, Luther MF, Eddy CA, Siler-Khodr TM, King TS and Schenken RS (1999) Low-dose follicular phase cocaine administration disrupts menstrual and ovarian cyclicity in rhesus monkeys Journal of the Society for Gynecologic Investigation 6 88-94

Siegel RK (1982) Cocaine and sexual dysfunction: the curse of moma coca Journal of Psychoactive Drugs 14 71-74

Steger RW, Silverman AY, Johns A and Asch RH (1981) Interactions of cocaine and delta-9-tetrahydrocannabinol with the hypothalamichypophysial axis of the female rat Fertility and Sterility 35 567-572

Tang LK (1980) Effect of serum sex steroids on pituitary LH response to LHRH and LH synthesis American Journal of Physiology 238 E458-E462

Teoh SK, Mendelson JH, Woods BT, Mello NK, Hallgring E, Anfinsen P, Douglas A and Mercer G (1993) Pituitary volume in men with concurrent heroin and cocaine dependence Journal of Clinical Endocrinology and Metabolism 76 1529-1532

Teoh SK, Mello NK and Mendelson JH (1994) Effects of drugs of abuse on reproductive function in women and pregnancy. In Addictive Behaviors in Women pp 437-473 Ed. R Watson. Humana Press, Clifton

Received 20 February 2001

First decision 5 April 2001.

Final version received 13 June 2001.

Accepted 21 June 2001. 